\title{
Maize Productivity, Economic Returns and Phosphorus Use Efficiency as Influenced by Lime, Minjingu Rock Phosphate and NPK Inorganic Fertilizer
}

\author{
Rodah P. Cheptoek ${ }^{1 *}$, Harun I. Gitari ${ }^{1}$, Benson Mochoge ${ }^{1}$, Oscar M. Kisaka ${ }^{2}$, Erick \\ Otieno $^{1}$, Sagar Maitra ${ }^{3}$, Jamal Nasar ${ }^{4}$ and Mahmoud F. Seleiman ${ }^{5}$
}

\begin{abstract}
${ }^{1}$ Department of Agricultural Science and Technology, School of Agriculture and Enterprise Development, Kenyatta University, P.O. Box 43844-00100, Nairobi, Kenya

${ }^{2}$ Department of Agroforestry and Rural Development, School of Natural Resources and Environment Management, University of Kabianga, Kenya

${ }^{3}$ Centurion University of Technology and Management, Odisha, India

${ }^{4}$ College of Resources and Environmental Sciences/Key Laboratory of Sustainable Utilization of Soil Resources in the Commodity Grain Bases in Jilin Province, Jilin Agricultural University, Changchun, China

${ }^{5}$ Plant Production Department, College of Food and Agriculture Sciences, King Saud University, Riyadh, 11451, Saudi Arabia
\end{abstract}

"Corresponding author: psiwa.cheptoek@students.ku.ac.ke

Received: $20-03-2021$

Revised: 23-05-2021

Accepted: $13-06-2021$

\begin{abstract}
This study was conducted to examine the effects of Lime, Minjingu Rock Phosphate (MRP) and inorganic NPK fertilizer on maize productivity, profitability and phosphorus use efficiency (PUE) based on grain yield $\left(\mathrm{PUE}_{\mathrm{Y}}\right.$ ) and economic returns ( $\left.\mathrm{PUE}_{\mathrm{E}}\right)$. The study was carried out for two rain seasons in Kenya and the treatments were Lime, MRP, NPK, Lime + MRP, Lime + NPK, and a control. The highest height (185 $\mathrm{cm})$ was recorded in MRP treated plots whereas the lowest values were observed in control $(162 \mathrm{~cm})$ and Lime $(166 \mathrm{~cm})$. The lowermost yield of $2.2 \mathrm{t} \mathrm{ha}^{-1}$ was attained from the non-amended plots. The value increased by 4.0, 2.9, 1.8, 1.7 and $0.8 \mathrm{t} \mathrm{ha}^{-1}$ in MRP, NPK, Lime + MRP, Lime + NPK and Lime treatments. The use of MRP proved to be the most lucrative with a disposable income of US\$2122ha-1. PUE $\mathrm{F}_{\mathrm{Y}}$ was such that Lime + NPK (95 kg of maize grain yield for every $\mathrm{kg}$ of p supplied $)<$ Lime + MRP $(116)<$ NPK $(125)$ $<$ control (139) < MRP (170) < Lime (188) whereas PUE $_{\mathrm{E}}$ was lowest in plots treated with Lime + NPK (38 $\left.\$ \mathrm{~kg}^{-1}\right)$ and Lime $+\mathrm{MRP}\left(46 \$ \mathrm{~kg}^{-1}\right)$, and highest in Lime $\left(75 \$ \mathrm{~kg}^{-1}\right)$ and MRP $\left(68 \$ \mathrm{~kg}^{-1}\right)$ plots. The results from the study indicate that MRP amendment is essential in optimizing not only maize productivity and economic returns but also phosphorus efficacy.
\end{abstract}

Keywords: Maize, Phosphorus, Minjingu rock phosphate, Soil acidity, Soil fertility

Soils in most parts of Kenya are generally infertile (FAO, 2001) and are characterized by nutrient imbalances such as potassium (K), phosphorus $(\mathrm{P})$ and nitrogen $(\mathrm{N})$ majorly caused by excessive uptake by crops with minimal replenishment (Gitari et al. 2019; Mugo et al. 2021; Ochieng' et al. 2021). Maize (Zea mays L.), which is a basic food item in Kenya is grown in soils characterized by low $\mathrm{pH}$ (Nyoro et al. 2004; Nduwimana et al. 2020) with low plant-available phosphorus $(\mathrm{P})$, particularly in
Western Kenya (Okalebo, 2009; Kisinyo et al. 2009). Therefore, acid soilsare normally infertile with poor plant growth caused by one or more interacting factors such as the buildup of manganese (Mn) or aluminium (Al) toxicities. Such factors have

How to cite this article: Cheptoek, R.P., Gitari, H.I., Mochoge, B., Kisaka, O.M., Otieno, E., Maitra, S., Nasar, J. and Seleiman, M.F. (2021). Maize Productivity, Economic Returns and Phosphorus Use Efficiency as Influenced by Lime, Minjingu Rock Phosphate and NPK Inorganic Fertilizer. International Journal of Bioresource Science, 08(01): 47-60.

Source of Support: None; Conflict of Interest: None 
adverse effects on soil microbial activities and many nutrient deficiencies for instance phosphorus $(\mathrm{P})$, potassium $(\mathrm{K})$, magnesium $(\mathrm{Mg})$, calcium $(\mathrm{Ca})$ and molybdenum (Mo) (Kamprath, 2015; Gudu et al. 2005; Hassan et al. 2020; Ngugi et al. 2021). Due to low and declining fertility, maize (grain) yield has stagnated at an average of $2 \mathrm{t} \mathrm{ha}^{-1}$, a value that is below the attainable $6 \mathrm{t} \mathrm{ha}^{-1}$ (Kang'ethe, 2004; Ochieng' et al. 2021).

Maize responds to $\mathrm{P}$ application significantly even at low rates of about $10 \mathrm{~kg} \mathrm{P}^{-1}$ (Jama et al. 1997; Waigwa et al. 2002; Kisinyo et al. 2009) suggesting the need of adding the nutrient seasonally to soils in this area to prevent not only its deficiency but also to reinstate and improve soil productivity. Major staple foods in Kenya such as maize, legumes and most of the horticultural crops perform very poorly on acidic soils (Nduwimana et al. 2020). Poor growth results in poor quality produce, low quantity of yields and low economic returns, a circumstance that results in food shortages, recurrent hunger, malnutrition crisis and eventually loss of lives (Nekesa et al. 2011; Nyawade et al. 2020). There have been suggestions of using improved and certified seeds but unfortunately, maize germplasm that most farmers use are quite sensitive to high aluminium saturation (less than 20\%), which is prevalent in many parts of Kenya (Ligeyo et al. 2008, 2013; Guignard et al. 2017).

The soil acidity mainly results from continuous use of fertilizers like Diammonium phosphate (DAP) during sowing given that they have an acidifying effect and nutrients being carried away through runoff water (Nyawade et al. 2019; Gitari et al. 2019). Many soil fertility management innovations and technologies have been tried to mitigate this problem such as the application of inorganic fertilizers and multiple cropping (Sanginga and Woomer, 2009; Maitra et al. 2020; Otieno et al. 2021). Such strategies have several disadvantages, hence inhibiting their adoption in Kenya by smallholder farmers. Therefore, the application of lime and Minjingu Rock Phosphate (MRP) to acidic soils is highly recommended to restore fertility and improve crop productivity (Jafer and Hailu, 2017; Gitari et al. 2015; Goulding, 2016). These amendments encompass $\mathrm{Mg}$ and or $\mathrm{Ca}$ composites that dislocate $\mathrm{Fe}^{3+}, \mathrm{Al}^{3+}$ and $\mathrm{H}^{+}$ions from exchangeable sites in soil colloids thus reducing $\mathrm{P}$ sorption sites in acidic soils, hence, increasing accessible P for plant uptake (Sanchez et al. 1997; Tisdale et al. 1990; Lino et al. 2018).

Additionally, use of NPK fertilizers is recommended because it has a less acidifying effect than DAP. With regard to NPK, $\mathrm{N}$ is available to plants in form of nitrate $\left(\mathrm{NO}_{3}^{-}\right)$, which releases $\mathrm{OH}^{-}$into the soil solution thereby raising the soil $\mathrm{pH}$. On the contrary, $\mathrm{N}$ in DAP is accessible to plants in ammonium $\left(\mathrm{NH}_{4}^{+}\right)$form, which releases $\mathrm{H}^{+}$into the solution that decreases soil $\mathrm{pH}$. Minjingu rock phosphate (MRP) is another soil amendment, which is a superlative phosphatic fertilizer ideal for highly acidic soils (Sanchez et al. 1997; Nekesa et al. 2011; Jama et al. 1997). Therefore, there is a need to amend soils in Kakamega County by using various soil amendments such as MRP, NPK and lime to improve phosphorus availability in soils, which will eventually improve maize productivity and economic benefits per unit area. It is against this background that this study was set with three objectives: (i) to evaluate the influence of Lime, MRP and NPK fertilizer on maize growth parameters (ii) to assess the effect of these treatments on crop produce (grain yield) and economic benefits and (iii) to examine the influence of same treatments on phosphorus uptake and use efficiency.

\section{RESEARCH METHODOLOGY}

\section{Experimental site}

This field study was carried out for two rain seasons (short rains of 2019 and long rains of 2020) at Bukura Agricultural Training Centre in Western Kenya,

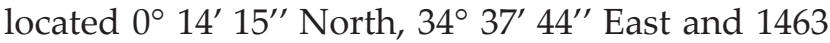
$\mathrm{m}$ above sea level. It is located in the Lower Midland agro-ecological zone (LM1), mainly dubbed the sugar cane zone, and with Orthic Ferralsols as the dominant soil type (FAO-UNESCO, 1990). The area receives approximately $1900 \mathrm{~mm}$ of rainfall per annum, which is well distributed over the two main cropping seasons; the short rains that run between August and December and the long rains that occur from March to July. The annual mean temperature is roughly $22^{\circ} \mathrm{C}$ with a range of $10^{\circ} \mathrm{C}$ and $26^{\circ} \mathrm{C}$. Specifically, during the short rains, total rainfall of $1044 \mathrm{~mm}$ was received whereas in 2020 long rains the rainfall amounted to $1092 \mathrm{~mm}$ (Fig. $1)$. The highest rainfall intensity was received in October (344 mm) and March (346 mm). Throughout 


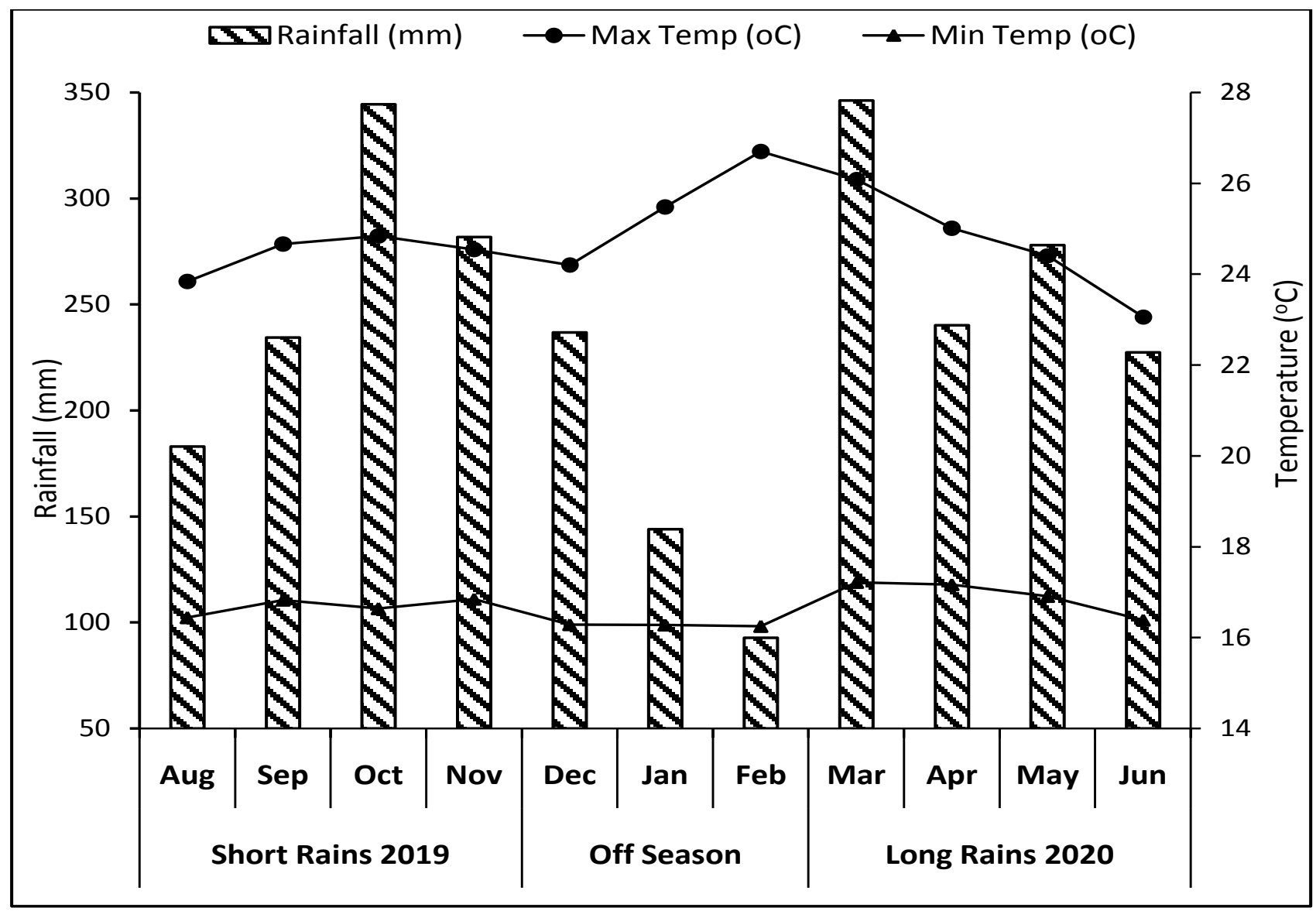

Fig. 1: Monthly total rainfall and mean temperature (minimum and maximum) as recorded at Bukura Agricultural College Meteorological Station from August 2019 to June 2020

the off-season (December 2019 to February 2020), about $470 \mathrm{~mm}$ of rainfall was received. The mean air temperature raised gradually to the highest value $\left(27^{\circ} \mathrm{C}\right)$ in February then decreased gradually to the lowest value of $16{ }^{\circ} \mathrm{C}$ in June.

\section{Experimental design and layout}

The experiment adopted a Randomized Complete Block Design (RCBD) with three replications where each experimental unit measured $5 \mathrm{~m}$ long by $4.5 \mathrm{~m}$ wide making a net area of $22.5 \mathrm{~m}^{2}$ plot $^{-1}$. The gross plot had four harvestable rows and two border rows. The blocks and plots were separated by paths of $0.8 \mathrm{~m}$ and $0.5 \mathrm{~m}$, respectively. There were six treatments for this experiment (Lime, MRP, NPK, Lime + MRP, Lime + NPK, and a control), which were replicated three times.

\section{Soil sampling and preparation for analysis}

Soil sampling was carried out using a soil auger approximately three weeks (21 days) before the onset of 2019 short rains. The samples were obtained from 22 points that were uniformly distributed along zigzag transects on the site at a depth of 0-0.3 $\mathrm{m}$ as described by Pennock and Yates (2008). The samples were mixed scrupulously then a composite sample was drawn for physical (texture) and chemical analyses. This disturbed sample was air-dried for three days and sieved through a $2 \mathrm{~mm}$ sieve. In addition, undisturbed soil samples were taken in core rings measuring $2.5 \mathrm{~cm}$ in radius and $5 \mathrm{~cm}$ in length.

Soil texture was determined by employing hydrometer procedures (Gee and Bauder, 1979) while bulk density was analyzed as described by Doran and Mielke (1984). Measurement of soil pH was done in 1:2.5 v/v (soil: water solution) with the help of a pH meter as explained by Ryan et al. (2001). Exchange acidity was determined according to Mehlich (1976) by leaching the soil with $0.6 \mathrm{~N} \mathrm{BaCl}_{2}$. Cations $\left(\mathrm{Na}^{+}, \mathrm{K}^{+}, \mathrm{Mg}^{2+}\right.$ and $\left.\mathrm{Ca}^{2+}\right)$ were determined using Atomic Absorption Spectrophotometer (AAS) 
(Jackson, 1967). Bray 1 method (Aura, 1978), was employed in the determination of phosphorus using the double acid extraction method and the concentration read on UV-vis spectrophotometer (Murphy and Riley, 1962). For the determination of total nitrogen $(\mathrm{N})$, the Kjeldahl digestion method was used (Bremner and Keeney, 1965). Soil organic carbon (OC) determination was done following Walkley-Black (wet oxidation) method (Yeomans and Bremner, 1988).

\section{Site preparation, planting and crop management}

Prior to instituting this experiment, the site had lied uncultivated for four seasons. Hence, the bush was cleared three weeks before the onset of short (July 2019) rains followed by deep ploughing and harrowing to achieve the recommended tilth. Agricultural lime $\left(\mathrm{CaCO}_{3}\right)$ was evenly broadcasted on the soil surface and thoroughly integrated into the top $2.5 \mathrm{~cm}$ layer using a rake to lime treated plots before actual planting. The fertilizers were applied at planting time in the holes where they were mixed with soil to avert seed scorching. Maize (variety- SC DUMA 43) obtained from local agrovet dealers was used as the test crop at the rate of $55 \mathrm{~kg} \mathrm{ha}^{-1}$.

Sowing was done on August 28, 2019, and March 25,2020 , for short and long rains, respectively. Seeds were sown manually at a depth of $0.075 \mathrm{~m}$ (two seeds per hole) at an inter-row spacing of $0.75 \mathrm{~m}$ with the intra row space being $0.25 \mathrm{~m}$. Thinning (removal of extra plants) was done around 14 days after sowing to be left with one plant per hole when the young plants were at the 3-4 leaf stage. Where there was germination failure, gapping was done immediately to achieve a plant population of 5.3 plants $\mathrm{m}^{-2}$. Cultural practices such as weed, pest and disease control were carried out uniformly in all plots. Weeding was done manually and fall armyworm control was done using Escort pesticide containing Emamectin benzoate $19 \mathrm{~g} \mathrm{~L}^{-1}$ as the active ingredient. All treatments were supplied with 75 $\mathrm{kg} \mathrm{N}$ ha $^{-1}$ calcium ammonium nitrate (26-0-0) as top-dress.

\section{Data collection procedures and analyses}

Data on plant leaf area (LA), leaf area index (LAI), height, and phosphorus uptake were collected at two maize phenological stages based on Biologische Bundesarstalt Bundessoztenamt and Chemical industry (BBCH) scales (Hack, 1992). The first stage was $\mathrm{BBCH}-19$, characterized by at least eight unfolded leaves whereas the second was BBCH-59 marked by a fully emerged and separated tassel. The yield data were collected at $\mathrm{BBCH}-89$ when maize was fully ripe with hard and shiny kernels. A section with a net area of $2 \mathrm{~m}^{2}$ was identified and marked at the centre of each plot. From this area, four plants were selected then tagged randomly for data collection.

The plant height was measured from the surface of the soil up to the collar of the upper leaf (with developed leaf sheath)using a steel tape measure. LAfor each plant was determined as a product of the leaf width (taken from the widest middle portion of the leaf) and the length and then multiplying it by 0.75, a correction factor (cf) for maize (Rajeshwari et al. 2007). LAI on the other hand was estimated by multiplying the total LA of the plant with the corresponding number of leaves plant ${ }^{-1}$ and dividing it with the space occupied by a single maize stand (Sadik et al. (2001) (Equation 1).

$L A I=\frac{\text { leaf area }\left(\mathrm{cm}^{2} / \text { plant }\right) * \text { leaf number }}{\text { ground area }\left(\mathrm{cm}^{2} / \text { plant }\right)}$

Besides the plant height, LA and LAI, additional data on P uptake were taken. This involved sampling plant tissues at $\mathrm{BBCH}-19$ and $\mathrm{BBCH}-59$, where two maize plants plot $^{-1}$ were selected randomly, cut and chopped with a machete. The samples were then mixed and a representative sample (weighing about one kilogram) taken and packaged in khaki paper bags, oven-dried to a persistent weight at $60{ }^{\circ} \mathrm{C}$ and ground. The dry ashing method as described by Motsara and Roy (2008) was used to measure the concentration level of $\mathrm{P}$ in the plant sample. One gram of the sample was ashed at $500-600^{\circ} \mathrm{C}$, placed in a silica crucible, and then heated in a furnace for 4 hours. The ash residue was dissolved in diluted hydrochloric acid $(\mathrm{HCl})$ then the solution was filtered gently into $250 \mathrm{ml}$ volumetric flasksto remove dehydrated silica and filled up to the mark. This was followed by a transfer of a $25 \mathrm{ml}$ aliquot of the plant solution into another volumetric flask (100 ml capacity) where distilled water was added to have a total volume of $70 \mathrm{ml}$. The reagent, consisting of $10 \mathrm{ml} 2.5 \%$ ammonium molybdate and 
$4 \mathrm{ml}$ of $0.25 \%$ aminonaphthol sulfonic acid were added. The volumetric flask was gently shaken and left to stand for ten minutes after which it was filled to the mark. The solution was permitted to stand for about 2 hours for full color development and its concentrations read on a colorimeter spectrophotometer at 430 nanometers.

\section{Grain yield and economic analysis}

At the BBCH-89 phenological stage, cobs from 4 plants plot $^{-1}$ were randomly selected and sun-dried separately for 7 days. Shelling was done manually and thereafter, the dry grains were weighed with a weighing balance to determine grain yield in kilograms and then converted to $t \mathrm{ha}^{-1}$. The total cost of production was determined by summing up all the expenses used in the production (fertilizer, seeds, pesticides and labor) including the cost of leasing the land (20 US\$ ha-1). Gross income was obtained by multiplying the grain yield with the

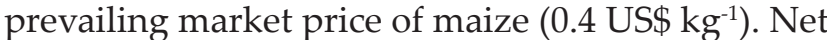
income and cost: benefit ratios were determined as shown in Equations 2 and 3.

Net income $=$ Gross income - Total cost of production

Cost: Benefit ratio $=\frac{\text { Net income }}{\text { Total cost of production }}$

\section{Determination of phosphorus use efficiency}

Phosphorus use efficiency (PUE) was computed using Equation 4 (Fageria, 2009; Gitari et al. 2018).

$P U E=\frac{Y}{P \text { applied }}$
Where $Y=$ yield obtained per treatment based on either grain yield $\left(\mathrm{PUE}_{\mathrm{Y}}\right)$ or economic $\left(\mathrm{PUE}_{\mathrm{E}}\right)$ terms. In this case, the economic returns were taken as the net income.

\section{Statistical analysis}

Each parameter was carefully studied and the average was calculated accordingly. The combined ANOVA for the two consecutive cropping seasons (2019 short rains and 2020 long rains) data was performed using GenStat (2010). Mean separation and interpretation were done according to the LSD test $(p \leq 0.05)$. Moreover, regression analysis was used to indicate the relationship between LAI and maize grain yield.

\section{RESULTS}

\section{Soil physical and chemical properties of the experimental site}

At the beginning of the experiment, analyses of the soil at the study site indicated it had a mean bulk density of $1.03 \mathrm{~g} \mathrm{~cm}^{-3}$ and clay loam texture with clay, silt and sand of 300, 400 and $300 \mathrm{~g} \mathrm{~kg}^{-1}$, respectively (Table 1$)$. It was relatively acidic $(\mathrm{pH}$ of 5.05) and with exchangeable acidity of $8.2 \mathrm{cmol}$ $\mathrm{kg}^{-1}$. Organic carbon, available $\mathrm{P}$ and total $\mathrm{N}$ were $15.3 \mathrm{~g} \mathrm{~kg}^{-1}, 3.83 \mathrm{mg} \mathrm{kg}^{-1}$ and $2.6 \mathrm{~g} \mathrm{~kg}^{-1}$, respectively. Its exchangeable cations: $\mathrm{Na}, \mathrm{K}, \mathrm{Ca}$ and $\mathrm{Mg}$ were averaged at $0.32,0.08,3.21$ and $1.31 \mathrm{cmol} \mathrm{kg}^{-1}$, respectively.

\section{Effect of soil amendments on maize growth parameters}

Plant height: Soil amendments had a substantial ( $p$ $\leq 0.05$ ) influence on plant height both at $\mathrm{BBCH}-19$

Table 1: Soil chemical and physical properties of the study site at $0-0.3 \mathrm{~m}$ depth

\begin{tabular}{llll}
\hline Physical properties & Value & Chemical properties & Value \\
\hline Sand $\left(\mathrm{g} \mathrm{kg}^{-1}\right)$ & 300 & $\mathrm{pH}($ water $) 1: 2.5$ & 5.05 \\
Clay $\left(\mathrm{g} \mathrm{kg}^{-1}\right)$ & 300 & Exchangeable $\mathrm{Na}\left(\mathrm{cmol} \mathrm{kg}^{-1}\right)$ & 0.32 \\
Silt $\left(\mathrm{g} \mathrm{kg}^{-1}\right)$ & 400 & Exchangeable $\left.\mathrm{K}(\mathrm{cmol} \mathrm{kg})^{-1}\right)$ & 0.08 \\
Textural class & Clay loam & Exchangeable $\mathrm{Ca}(\mathrm{cmol} \mathrm{kg}-1)$ & 3.21 \\
Bulk density $\left(\mathrm{g} \mathrm{cm}^{-3}\right)$ & 1.03 & Exchangeable $\mathrm{Mg}(\mathrm{cmol} \mathrm{kg})^{-1}$ & 1.31 \\
& & Exchangeable acidity $\left(\mathrm{cmol} \mathrm{kg}^{-1}\right)$ & 8.2 \\
& & Organic carbon $\left(\mathrm{g} \mathrm{kg}^{-1}\right)$ & 15.3 \\
& & Total N $\left(\mathrm{g} \mathrm{kg}^{-1}\right)$ & 2.6 \\
& & Available $\mathrm{P}\left(\mathrm{mg} \mathrm{kg}^{-1}\right)$ & 3.83 \\
\hline
\end{tabular}




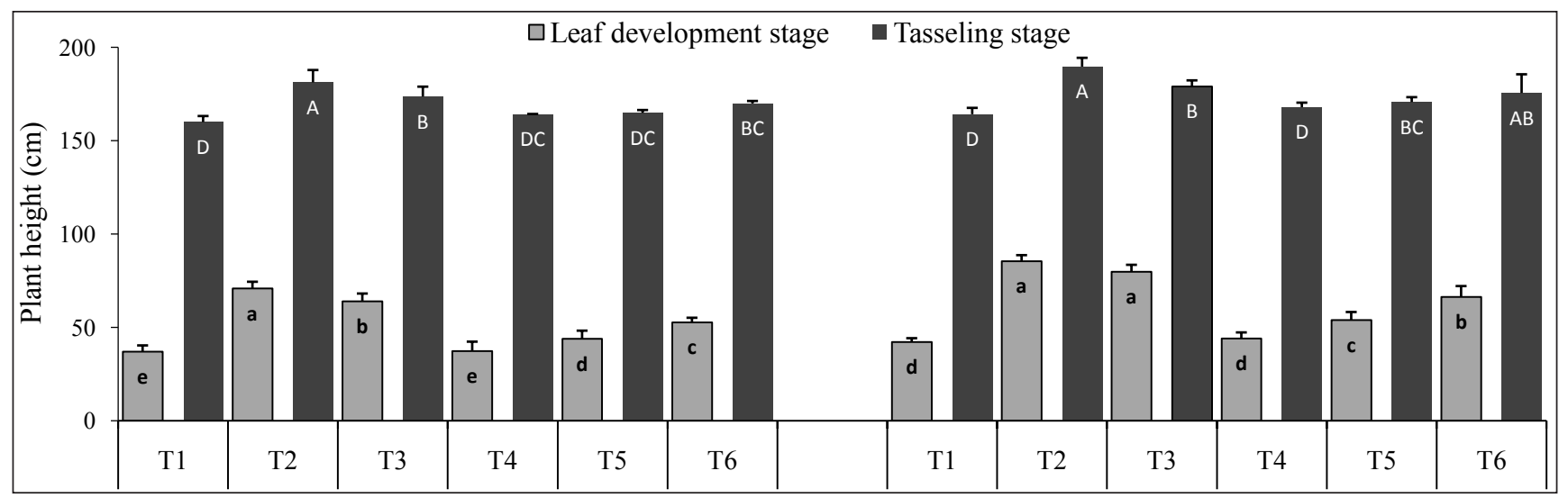

Fig. 2: Plant height at leaf development (gray bars) and tasseling stages (black bars) in 2019 short rains and 2020 long rains as affected by different amendments: Control (no amendment applied) (T1); Minjingu rock phosphate (MRP) (T2); NPK (T3); Lime (T4); Lime + NPK (T5) and Lime + MRP (T6). Bars with the similar alphabet letters (lower case for leaf development and upper case for tasseling) within the same growth stage and season represent means that are substantially the same at $\mathrm{p} \leq 0.05$. Error bars show standard error of the means

and $\mathrm{BBCH}-59$ scales and the effect differed with seasons (Fig. 2). Across the seasons, generally at BBCH-19 (leaf development) stage, plant heights according to treatments were: the control $(38 \mathrm{~cm})<$ Lime $(41 \mathrm{~cm})<$ Lime + NPK $(49 \mathrm{~cm})$ Lime + MRP $<$ $(60 \mathrm{~cm})<\operatorname{NPK}(72 \mathrm{~cm})<\operatorname{MRP}(78 \mathrm{~cm})$. On the other hand, the highest height $(185 \mathrm{~cm})$ at the tasseling stage was recorded in MRP treated plots whereas the least values were recorded in the control (162 $\mathrm{cm})$ and Lime $(166 \mathrm{~cm})$ treatments. The heights with Lime + NPK treatment differed slightly from those with NPK and Lime + MRP but not with lime treated plots.

Leaf area and leaf area index: Leaf area (LA) and leaf area index (LAI) were considerably ( $p$ $\leq 0.05$ ) affected by soil amendments both at leaf development and tasseling stages with lower values being recorded in 2019 short rains compared with 2020 long rains (Table 2). Across the seasons, LA at the leaf development stage was lowest in the control $\left(0.16 \mathrm{~cm}^{2}\right)$ and in lime treated plots $\left(0.17 \mathrm{~cm}^{2}\right)$ with an intermediate value of $0.20 \mathrm{~cm}^{2}$ in Lime + NPK and highest record value of $0.42 \mathrm{~cm}^{2}$ in plots that received MRP. Plots treated with NPK + Lime and MRP recorded 24 and 31\% lower LA, respectively, when compared with those amended with MRP $\left(0.42 \mathrm{~cm}^{2}\right)$. At tasseling stage, the variable differed between treatments whereby it increased in the order of control $\left(0.48 \mathrm{~cm}^{2}\right)<$ Lime $\left(0.59 \mathrm{~cm}^{2}\right)<$ Lime $+\operatorname{NPK}\left(0.64 \mathrm{~cm}^{2}\right)<$ Lime $+\operatorname{MRP}\left(0.71 \mathrm{~cm}^{2}\right)<$ NPK $\left(0.83 \mathrm{~cm}^{2}\right)<\operatorname{MRP}\left(0.97 \mathrm{~cm}^{2}\right)$. At the leaf development stage, LAI was lowest in control (0.73), followed by Lime (0.75) and Lime + NPK (0.89) treatments while the highest value was noted in the plot that received MRP (1.86). The LAI in NPK treatment did not differ from that in Lime + MRP treated plots. At the tasseling stage, the highest (4.3) LAI was observed in plots that received MRP while the lowest record was made in control (2.1) and lime-amended (2.6) plots. Lime + NPK, Lime + MRP and NPK recorded 34, 27 and 14\% lower values for LAI, respectively, compared with MRP.

\section{Effect of soil amendments on maize grain yield and economic returns}

Maize grain yield and economic returns were substantially $(p \leq 0.05)$ influenced by soil amendments with higher values being recorded in 2020 long rains compared with 2019 short rains (Table 3). Across the seasons, the least yield (2.2 t $\mathrm{ha}^{-1}$ ) was noted in non-amended control plots. MRP treated plots recorded $4.0 \mathrm{t} \mathrm{ha}^{-1}$ higher than control whereas NPK, lime, Lime + NPK and Lime + MRP treatments recorded 2.9, 0.8, 1.7 and $1.8 \mathrm{t} \mathrm{ha}^{-1}$ higher values, respectively, compared with control. The cost of production ranged from US\$ 246 in control to US\$ 381 in Lime + NPK plots. Nevertheless, the use of MRP proved to be the most rewarding with a net income of US\$ 2122 with NPK, Lime + MRP, Lime + NPK, Lime and control recording 22, 40, 45, 10 and $70 \%$ lower values, respectively, compared with MRP. This resulted in greater benefit: cost ratios in plots that received MRP and NPK (7.6 and 5.9, respectively) and lowest in Lime and nonamended treated plots (2.51 and 2.53, respectively). 
Table 2: Leaf area and leaf area index (means \pm standard error) at leaf development (BBCH-19) and tasseling (BBCH-59) stages as affected by soil amendments in 2019 short rains and 2020 long rains

\begin{tabular}{|c|c|c|c|c|c|}
\hline \multirow[b]{2}{*}{ Season } & \multirow[b]{2}{*}{ Treatment } & \multicolumn{2}{|c|}{ Leaf area } & \multicolumn{2}{|c|}{ Leaf area index } \\
\hline & & $\begin{array}{l}\text { BBCH-19 } \\
\left(\mathrm{m}^{2}\right)\end{array}$ & $\begin{array}{l}\text { ВBCH-59 } \\
\left(\mathrm{m}^{2}\right)\end{array}$ & ВВСН-19 & ВВСН-59 \\
\hline Short & MRP & $0.39 \pm 0.03^{a}$ & $0.88 \pm 0.03^{a}$ & $1.74 \pm 0.42^{\mathrm{a}}$ & $3.90 \pm 0.53^{a}$ \\
\hline \multirow[t]{3}{*}{ rains } & NPK & $0.30 \pm 0.04^{a}$ & $0.77 \pm 0.02^{\mathrm{bc}}$ & $1.33 \pm 0.08^{b}$ & $3.41 \pm 0.06^{\mathrm{ab}}$ \\
\hline & Lime & $0.16 \pm 0.01^{b}$ & $0.54 \pm 0.02^{\mathrm{ed}}$ & $0.70 \pm 0.61^{\mathrm{c}}$ & $2.39 \pm 1.01^{\mathrm{cd}}$ \\
\hline & Lime + MRP & $0.29 \pm 0.03^{a}$ & $0.69 \pm 0.04^{c}$ & $1.27 \pm 0.12^{\mathrm{b}}$ & $3.04 \pm 0.18^{\mathrm{b}}$ \\
\hline 2020 & Control & $0.18 \pm 0.01^{c}$ & $0.50 \pm 0.03^{\mathrm{d}}$ & $0.78 \pm 0.27^{c}$ & $2.22 \pm 0.30^{\mathrm{d}}$ \\
\hline Long & MRP & $0.44 \pm 0.01^{\mathrm{a}}$ & $1.06 \pm 0.05^{\mathrm{a}}$ & $1.97 \pm 0.28^{\mathrm{a}}$ & $4.70 \pm 0.40^{\mathrm{a}}$ \\
\hline \multirow{2}{*}{ rains } & NPK & $0.33 \pm 0.03^{b}$ & $0.89 \pm 0.08^{\mathrm{ab}}$ & $1.48 \pm 0.16^{\mathrm{b}}$ & $3.96 \pm 0.10^{\mathrm{ab}}$ \\
\hline & Lime & $0.18 \pm 0.02^{c}$ & $0.64 \pm 0.01^{\mathrm{c}}$ & $0.79 \pm 0.42^{c}$ & $2.83 \pm 0.63^{c}$ \\
\hline \multicolumn{2}{|c|}{ Season $(S)$} & 0.003 & $<.001$ & 0.003 & $<.001$ \\
\hline \multicolumn{2}{|l|}{$\mathrm{T} \times \mathrm{S}$} & 0.652 & 0.040 & 0.652 & 0.040 \\
\hline
\end{tabular}

Means ( \pm standard deviation) bearing dissimilar alphabet letters (down the column and per season) differ markedly at $p \leq 0.05$ by LSD test.

Table 3: Maize yield and economic returns (means \pm standard error) as influenced by soil amendments in 2019 short rains and 2020 long rains

\begin{tabular}{|c|c|c|c|c|c|c|}
\hline Season & Treatment & Yield (t ha-1) & $\begin{array}{l}\text { Cultivation } \\
\text { cost (US\$ ha-1) }\end{array}$ & $\begin{array}{l}\text { Gross income } \\
\left(\mathrm{US} \$ \mathrm{ha}^{-1}\right)\end{array}$ & $\begin{array}{l}\text { Net income } \\
\left(\mathrm{US \$} \mathrm{ha} \mathrm{h}^{-1}\right)\end{array}$ & $\begin{array}{l}\text { Benefit: cost } \\
\text { ratio }\end{array}$ \\
\hline 2019 & Control & $2.04 \pm 0.20^{\mathrm{e}}$ & 246.81 & $816 \pm 81.18^{e}$ & $569.19 \pm 81.18^{d}$ & $2.31 \pm 0.36^{\mathrm{d}}$ \\
\hline Short & MRP & $5.86 \pm 0.21^{\mathrm{a}}$ & 281.18 & $2344 \pm 83.72^{\mathrm{a}}$ & $2062.82 \pm 83.72^{\mathrm{a}}$ & $7.34 \pm 0.32^{\mathrm{a}}$ \\
\hline \multirow{3}{*}{ rains } & NPK & $4.98 \pm 0.21^{b}$ & 297.60 & $1992 \pm 83.72^{b}$ & $1694.4 \pm 83.72^{b}$ & $5.69 \pm 0.30^{b}$ \\
\hline & Lime & $2.78 \pm 0.05^{\mathrm{d}}$ & 334.61 & $1112 \pm 20.46^{\mathrm{d}}$ & $777.39 \pm 20.46^{\mathrm{d}}$ & $2.32 \pm 0.07^{\mathrm{d}}$ \\
\hline & Lime + NPK & $3.68 \pm 0.20^{c}$ & 380.40 & $1472 \pm 81.18^{c}$ & $1091.6 \pm 81.18^{c}$ & $2.87 \pm 0.23^{\mathrm{cd}}$ \\
\hline 2020 & Control & $2.30 \pm 0.16^{\mathrm{e}}$ & 245.79 & $920 \pm 63.87^{e}$ & $674.21 \pm 63.87^{\mathrm{e}}$ & $2.74 \pm 0.28^{\mathrm{de}}$ \\
\hline Long & MRP & $6.16 \pm 0.18^{\mathrm{a}}$ & 281.30 & $2464 \pm 70.86^{\mathrm{a}}$ & $2182.7 \pm 70.86^{\mathrm{a}}$ & $7.76 \pm 0.27^{a}$ \\
\hline \multirow[t]{3}{*}{ rains } & NPK & $5.21 \pm 0.07^{b}$ & 296.65 & $2084 \pm 27.06^{b}$ & $1787.35 \pm 27.06^{b}$ & $6.03 \pm 0.10^{\mathrm{b}}$ \\
\hline & Lime & $3.10 \pm 0.04^{\mathrm{d}}$ & 335.50 & $1240 \pm 17.72^{\mathrm{d}}$ & $904.5 \pm 17.7^{\mathrm{d}}$ & $2.70 \pm 0.06^{\mathrm{e}}$ \\
\hline & Lime + NPK & $4.07 \pm 0.13^{c}$ & 381.47 & $1628 \pm 53.15^{c}$ & $1246.56 \pm 53.15^{c}$ & $3.28 \pm 0.15^{\mathrm{bc}}$ \\
\hline \multicolumn{2}{|c|}{ Season $(S)$} & $<.001$ & & $<.001$ & $<.001$ & $<.001$ \\
\hline \multicolumn{2}{|l|}{$\mathrm{T} \times \mathrm{S}$} & 0.703 & & 0.703 & 0.683 & 0.397 \\
\hline
\end{tabular}

Means with dissimilar alphabet letters (down the column) per season differ considerably at $p \leq 0.05$ by LSD test.

Lime + MRP and Lime + NPK recorded ratios of 3.5 and 3.1, respectively.

\section{Phosphorus uptake and $P$ use efficiency}

Phosphorus uptake and PUE were influenced considerably $(p \leq 0.05)$ by soil amendments and the effect differed with seasons. P uptake and PUE was higher in 2020 long rains as compared to 2019 short rains. Across the seasons, phosphorus uptake was high at tasseling (BBCH-59) than at the leaf development (BBCH-19) stage (Table 4). At the leaf development stage, significant differences among 
Table 4: Phosphorus (P) uptake at leaf development (BBCH-19) and tasseling (BBCH-59) stages and P use efficiency based on yield $\left(\mathrm{PUE}_{\mathrm{Y}}\right)$ and economic returns ( $\mathrm{PUE}_{\mathrm{E}}$ ) (means \pm standard error) as affected by treatments in 2019 short rains and 2020 long rains

\begin{tabular}{|c|c|c|c|c|c|}
\hline \multirow[b]{2}{*}{ Season } & \multirow[b]{2}{*}{ Treatment } & \multicolumn{2}{|c|}{ Phosphorus uptake } & \multicolumn{2}{|l|}{ Phosphorus use efficiency } \\
\hline & & $\begin{array}{l}\text { BBCH-19 } \\
\left(\mathrm{kg} \mathrm{ha}^{-1}\right)\end{array}$ & $\begin{array}{l}\text { BBCH-59 } \\
\left(\mathrm{kg} \mathrm{ha}^{-1}\right)\end{array}$ & $\begin{array}{l}\text { PUE }_{\gamma}(\mathrm{kg} \text { of grain } \\
\left.\text { yield kg of } p \text { applied }{ }^{-1}\right)\end{array}$ & $\operatorname{PUE}_{\mathrm{E}}\left(\$ \mathrm{~kg}^{-1}\right)$ \\
\hline 2019 & Control & $1.9 \pm 0.07^{c}$ & $2.1 \pm 0.02^{c}$ & $130.1 \pm 52.99^{b}$ & $52.0 \pm 21.20^{\mathrm{b}}$ \\
\hline Short & MRP & $2.7 \pm 0.04^{\mathrm{a}}$ & $6.9 \pm 0.04^{\mathrm{a}}$ & $165.9 \pm 8.91^{\mathrm{a}}$ & $66.4 \pm 3.56^{\mathrm{a}}$ \\
\hline \multirow[t]{4}{*}{ rains } & NPK & $2.2 \pm 0.04^{\mathrm{b}}$ & $3.5 \pm 0.02^{b}$ & $122.1 \pm 7.24^{\mathrm{b}}$ & $48.9 \pm 2.90^{\mathrm{b}}$ \\
\hline & Lime & $1.1 \pm 0.03^{c}$ & $2.2 . \pm 0.02^{\mathrm{c}}$ & $177.2 \pm 13.35^{a}$ & $70.9 \pm 5.34^{a}$ \\
\hline & Lime + NPK & $1.6 \pm 0.03^{c}$ & $2.9 \pm 0.02^{c}$ & $90.3 \pm 7.02^{c}$ & $36.1 \pm 2.81^{\mathrm{c}}$ \\
\hline & Lime + MRP & $1.8 \pm 0.04^{c}$ & $3.5 \pm 0.04^{\mathrm{b}}$ & $113.9 \pm 5.19^{c}$ & $45.6 \pm 2.08^{c}$ \\
\hline 2020 & Control & $1.9 \pm 0.04^{\mathrm{d}}$ & $2.3 \pm 0.01^{\mathrm{c}}$ & $147.2 \pm 41.69^{\mathrm{c}}$ & $58.8 \pm 16.68^{b}$ \\
\hline Long & MRP & $3.6 \pm 0.04^{\mathrm{a}}$ & $8.7 \pm 0.03^{\mathrm{a}}$ & $174.2 \pm 7.54^{\mathrm{b}}$ & $69.7 \pm 3.02^{\mathrm{a}}$ \\
\hline \multirow[t]{4}{*}{ rains } & NPK & $2.9 \pm 0.03^{b}$ & $3.9 \pm 0.03^{b}$ & $127.9 \pm 2.34^{\mathrm{d}}$ & $51.9 \pm 0.94^{\mathrm{b}}$ \\
\hline & Lime & $1.6 \pm 0.02^{\mathrm{d}}$ & $2.4 \pm 0.02^{c}$ & $198.0 \pm 11.56^{a}$ & $79.2 \pm 4.63^{\mathrm{a}}$ \\
\hline & Lime + NPK & $2.3 \pm 0.01^{c}$ & $2.6 \pm 0.03^{c}$ & $100.0 \pm 4.60^{\mathrm{e}}$ & $40.0 \pm 1.84^{c}$ \\
\hline & Lime + MRP & $2.2 \pm 0.05^{c}$ & $3.4 \pm 0.04^{b}$ & $117.8 \pm 5.65^{\mathrm{d}}$ & $47.1 \pm 2.26^{c}$ \\
\hline \multicolumn{6}{|c|}{ Summary of analyses of variance ( $p$ values) } \\
\hline Treatment $(\mathrm{T})$ & & $<.001$ & $<.001$ & $<.001$ & $<.001$ \\
\hline Season (S) & & $<.001$ & $<.001$ & $<.001$ & $<.001$ \\
\hline$T \times S$ & & 0.337 & 0.337 & 0.103 & 0.004 \\
\hline
\end{tabular}

Down the column (within a season), means with similar superscript alphabet letters are not substantially $(p \leq 0.05)$ different by LSD test.

the soil amendments in plant $\mathrm{P}$ uptake were found, with average values for both seasons of 3.2, 2.6, 2.0, 1.9, 1.8 and $1.4 \mathrm{~kg} \mathrm{ha}^{-1}$ in MRP, NPK, Lime + MRP, Lime + NPK, control and Lime treatments, respectively. Similarly, at the tasseling stage highest uptake was noted in MRP $\left(7.8 \mathrm{~kg} \mathrm{ha}^{-1}\right)$. Average plant P uptake in NPK, Lime + MRP, Lime + NPK, Lime and control-treated plots for the two seasons were significantly lower by 52, 55, 67, 71 and $72 \%$, respectively, relative to MRP. P use efficiency based on grain yield $\left(\mathrm{PUE}_{\gamma}\right)$ was such that Lime $+\mathrm{NPK}$ (95 kg of maize grain yield per $\mathrm{kg}$ of $\mathrm{p}$ supplied) $<$ Lime + MRP $(116)<$ NPK $(125)<$ control (139) < MRP $(170)<$ Lime (188). P use efficiency based on economic returns $\left(\mathrm{PUE}_{\mathrm{E}}\right)$ was lowest in plots treated with Lime + NPK (38 $\left.\$ \mathrm{~kg}^{-1}\right)$ and Lime + MRP (46 $\left.\$ \mathrm{~kg}^{-1}\right)$, and highest in Lime $\left(75 \$ \mathrm{~kg}^{-1}\right)$ and MRP $\left(68 \$ \mathrm{~kg}^{-1}\right)$ plots. NPK and control recorded 32 and $26 \%$ lower values, respectively, compared with that received lime.

\section{Relationship between yield and leaf area index}

When yield was regressed against leaf area index (LA1), strong relationships were noted in Lime +
NPK $\left(R^{2}=0.60\right)$ and Lime $\left(R^{2}=0.86\right)$ treatments, implying that with all factors held constant, increasing LAI by a unit would result in an increase in yield by 0.8 and $0.6 \mathrm{t} \mathrm{ha}^{-1}$, respectively (Fig. 3). Similarly, a positive but moderate association $\left(R^{2}=0.41\right)$ was observed between yield and MRP amended plots, an indication that increasing LAI by a unit would increase yield by $6 \%$. Nonetheless, the relationship between yield and NPK gave a weak coefficient of regression $\left(R^{2}=0.32\right)$ whereas, when yield in control and in plots that received Lime + MRP were regressed, no tangible relationship was established $\left(R^{2}=0.2\right)$.

\section{DISCUSSION}

\section{Effect of soil amendments on maize growth, yield and economic returns}

From the research study, the soil amendments substantially influenced plant height, leaf area and leaf area index, yield, economic returns and $P$ use efficiency with better maize performance being observed in 2020 long rains than 2019 short rains. During the 2019 short rain, maize supplied 
with lime recorded the shortest plant height. This could be as a result of the low neutralizing activity of lime which is associated with low rainfall (Fig. 1) hence low solubility of lime, which could have made it possible for aluminium ions to inhibit the uptake of available nutrients. In 2020 long rains, lime increased the maize growth compared with the un-amended control,and this could be accredited to the lime solubility into the soil due to sufficient rainfall received in the season, and also the activity of lime residues applied (Kimiti, 2018).

Better performance of MRP could be attributed to continuous slow discharge of Pinto the soil making it accessible by the plant. This could also be attributed to the extra plant nutrients $(5 \% \mathrm{~S}$, $0.5 \% \mathrm{Cu}, 0.1 \%$ Band $0.5 \% \mathrm{Zn}$ ) that are available in MRP fertilizer,unlike other commercial fertilizers. Hence, the study indicates higher superiority of using MRP as compared with the other treatments, which is as per other findings (Nekesa et al. 2011) that MRP provides a liming effect on acidic soils especially orthicferralsols, which are widely distributed in some regions of Western Kenya. This is ascribed to the relatively high content of carbonates despite their low solubility in the soil. In NPK, Lime + NPK, Lime + MRP and Lime plots, the yield increased correspondingly by 2.9, 1.7, 1.9 and $0.8 \mathrm{t} \mathrm{ha}^{-1}$, compared with non-amended plots. The control had the least yields, probably due to low available $\mathrm{P}$ where most of it was probably fixed by aluminium oxides in the acidic soils of the area. Hence, this rendered P unavailable or limited for the maize crop uptake (Gitari et al. 2015). Consequently, plants supplied with inadequate $\mathrm{P}$ exhibit purplebluish leaves, poor crop growth and poor crop performance in terms of economic yields. This agrees with the observation made by Marschner (1995) that phosphorus is an important nutrient

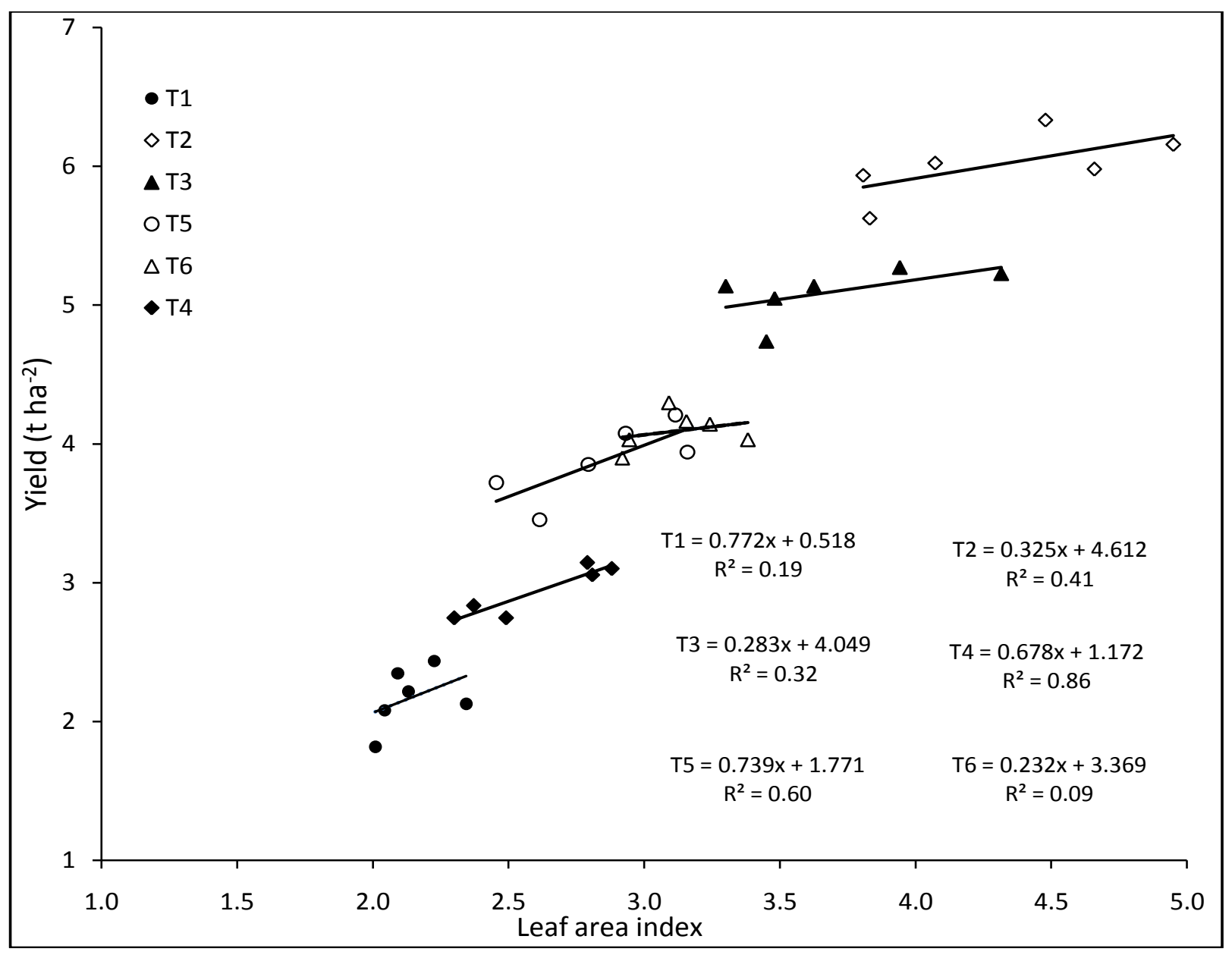

Fig. 3: Regression of yield against leaf area index for control (T1), MRP (T2), NPK (T3), Lime (T4), Lime + NPK (T5) and Lime + MRP (T6) 
in crop production, and its application to soils is essential to achieve maximum crop production.

Furthermore, higher yields achieved in MRP treatment could be as a result of large leaves denoted by LA and LAI, which could have enabled the plants to attain optimum photosynthetic capacity during the post tasseling period (Marschner, 1995; Uribelarrea et al. 2009; Nasar et al. 2021). Such argument is reinforced by previous observations made by Yan et al. (2011) and Raza et al. (2021) that plants with more leaves tend to have better growth and subsequent higher yield. This was further reinforced by the strong regression coefficients between yield and LAI, which agrees with the findings by Sandana (2016). Such associations may indicate that any factor that increases LAI would also increase grain yield (Seleiman et al. 2021). As noted by Zhou et al. (2019), optimal P supply corresponds well with a light interception, which enables the plant to utilize assimilates and meets their grain yield potential. Increased light interception not only results in increased photosynthetic capacity but also boosts carbon (c) translocation to the roots (Cheng et al. 2014; Wang et al. 2011; Zhou et al. 2021). In such cases, the partitioned $C$ serves not only as a source of energy but also as a nutritional signal in driving heightened nutrient uptake, hence productivity.

The highest net income of 2123 US $\$$ ha $^{-1}$ was noted in the treatment that received MRP, which was $71 \%$ higher than control. Lime treatments recorded low net income possibly due to high input cost and labour employed in the application of the lime. The higher economic returns in MRP treatment could be associated with the low cost of production associated with it since the rock was locally and cheaply available hence making it the most economically viable soil amendment for maize production.

\section{Effect of soil amendments on P uptake and P use efficiency}

In the current study, maize that received MRP had higher P uptake, which might have resulted in more leaves with increased photosynthetic capacity in comparison with those in control plots (Fig. 2 and Table 2). Possibly, low P availability in control plots curbed the crop's P uptake. This could further be explained by the low values that were noted for LA and LAI in such plots (Fig. 2 and Table 2). The results infer that $\mathrm{P}$ deficiency has an unfavourable effect on leaf growth (Wang and Ning, 2019). Sustaining sufficient $\mathrm{P}$ concentration in leaves cereal crops such as maize is essential for photosynthesis, which is recycled later and translocated to the developing grains during the reproductive growth stage (Sklensky and Davies, 1993; Yaseen and Malhi, 2009; Meng et al. 2013). These results are in agreement with the findings reported by Marschner (1995) that $\mathrm{P}$ is taken up largely during the active growth stage,which thereafter gets re-translocated into storage organs such as seeds during reproductive stages. In addition, Marschner (1995) observed that the amount of $\mathrm{P}$ supplied during such reproductive stages controls the subdivision of photosynthates between the source leaves and the reproductive organs such as grains thus resulting in vigorous growth.

From the study, average plant P uptake in NPK, Lime + MRP, Lime + NPK, Lime and controltreated plots were significantly lower by 52, 55, 67,71 and $72 \%$, respectively, relative to MRP. It can be concluded from this study that among all the treatments, MRP proved to be a superior soil amendment in terms of P uptake by maize crop. The higher P uptake could be ascribed to an increase in the availability of $\mathrm{P}$ in the soil as influenced by the addition of MPR (Nekesa et al. 2011). According to Kochian (2005) and Swift et al. (1994), low P uptake in other treatments particularly control could be due to crop's sensitivity to high Al saturation (> $20 \%$ ), which affects root development and growth of many crops thus making them inefficiently utilize the inherent $\mathrm{P}$ in the soil or added phosphate fertilizer (Schachtman et al. 1998; Faridvand et al. 2021; Soratto et al. 2021). Due to the low content of soil available phosphorus, maize production is not likely to increase without the addition of mineral or organic P (Vance et al. 2003; Veneklaas et al. 2012). As a result, availability of $\mathrm{P}$ has been associated with the application of $\mathrm{P}$ and increase in available $P$ from organic amendments or mineral fertilizers thus resulting in higher $\mathrm{P}$ uptake (Kwabiah et al. 2003; Dobermann et al. 2002). Improved P uptake with MRP application especially during the long rains of 2020 could be attributed to increased soil moisture content, which probably enhanced dissolution of MRP resulting in more available P. This is affirmed by Dhillon et al. (2020) and Gitari et al. (2020) who reported improved P uptake under 
higher rainfall condition. The well-distributed rainfall during the long rains ensured that the soil remained moist throughout the growing season, therefore, promoting the dissolution of $\mathrm{P}$, which met the plant P demands (Khasawneh and Doll 1978; Bolland et al. 1995).With higher P uptake, the higher yield was noted, especially in MPR treatment resulting in higher economic returns. Consequently, the higher yield and income translated to higher $\mathrm{P}$ efficacy. Thus, the current study demonstrates the feasibility of using MRP to increase not only maize productivity but also economic returns.

\section{CONCLUSION}

This study has demonstrated that the application of MRP improved maize growth. MRP treatment increased plant height by $14 \%$, leaf area by $50 \%$ and leaf area index by $51 \%$ compared with non-amended plots. In addition, the application of MRP fertilizer showed improved maize grain yields and economic returns compared with NPK treatment. For instance, the highest yields were obtained in MRP treatments $\left(6 \mathrm{t} \mathrm{ha}^{-1}\right)$. Average plant $\mathrm{P}$ uptake in NPK and control treatments were significantly lower by 52 and $72 \%$, respectively, compared with MRP. P use efficiency based on maize grain yield $\left(\mathrm{PUE}_{\gamma}\right)$ was highest in Lime and MRP treatments and lowest in NPK treatment. P use efficiency based on economic returns $\left(\right.$ PUE $\left._{\mathrm{E}}\right)$ was lowest in treatments with Lime + NPK (38 \$ $\left.\mathrm{kg}^{-1}\right)$ and highest in Lime $\left(75 \$ \mathrm{~kg}^{-1}\right)$ and MRP (68 \$ $\mathrm{kg}^{-1}$ ) treatments. Generally, MRP treatment proved to be the best soil amendment for optimal maize growth, productivity and phosphorus uptake and use efficiency. Nonetheless, since this study was done for only two rainy seasons, it would be useful to consider a longer experiment to establish the effects of these soil amendments on the observed parameters as well as soil properties.

\section{REFERENCES}

1. Bolland, M.D.A., Yeates, J.S. and Clarke, M.F. 1995. Effect of fertilizer type, sampling depth, and years on Colwell soil test phosphorus for phosphorus leaching soils. Fertilizer Research, 44(3): 177-188.

2. Bremner, J.M. and Keeney, D.R. 1965. Steam distillation methods for determination of ammonium, nitrate and nitrite. Analytica Chimica. Acta., 32: 485-495.

3. Cheng, L., Tang, X., Vance, C.P., White, P.J., Zhang, F. and Shen, J. 2014. Interactions between light intensity and phosphorus nutrition affect the phosphate-mining capacity of white lupin (Lupinus albus L.). Journal of Experimental Botany, 65: 2995-3003.

4. Dhillon, J., Torres, G., Driver, E., Figueiredo, B. and Raun, W.R. 2017. World phosphorus use efficiency in cereal crops. Agronomy Journal, 109(4): 1670-1677.

5. Dobermann, A., Witt, C., Dawe, D., Abdulrachman, S., Gines, H.C., Nagarajan, R., Satawathananont, S., Son, T.T., Tan, P.S., Wang, G.H., Chien, N.V., Thoa, V.T.K., Phung, C.V., Stalin, P., Muthukrishnan, P., Ravi, V., Babu, M., Chatuporn, S., Sookthongsa, J., Sun, Q., Fu, R., Simbahan, G.C. and Adviento, M.A.A. 2002. Site-specific nutrient management for intensive rice cropping systems in Asia. Field Crops Resources, 74(1): 37-66.

6. Doran, J.W. and Mielke, L.N. 1984. A rapid, low-cost method for determination of soil bulk density. Soil Science Society of America Journal, 48(4): 717-719.

7. Fageria, N.K. 2009. The use of Nutrients in Crop Plants. CRC Press, Boca Raton, Florida. USA: CRC Press, Experimental Agriculture, 45(3): 380-380.

8. FAO- Food and Agriculture Organization of United Nation. (2001). The state of food insecurity in the world 2001, Rome.

9. FAO-UNESCO. (1990). FAO-UNESCO Soil map of the world. Revised legend. World resources. The Report, 60 FAO, Rome.

10. Faridvand, S., Rezaei-Chiyaneh, E., Battaglia, M., Gitari, H., Raza, M.A. and Siddique, K.H.M. 2021. Application of bio and chemical fertilizers improves yield, and essential oil quantity and quality of Moldavian balm (Dracocephalum moldavica L.) intercropped with mung bean (Vigna radiata L.). doi: 10.1002/fes3.319.

11. Gee, G.W. and Bauder, J.W. 1979. Particle size analysis by hydrometer: A simplified method for routine textural analysis and a sensitivity test of measurement parameters. Soil Science Society of America Journal, 43: 1004-1007.

12. Genstat. 2010. Genstat Release 13.3 (PC/Windows 7). Copyright 2010, VSN International Ltd.

13. Gitari, H.I., Gachene, C.K.K., Karanja, N.N., Kamau, S., Nyawade, S. and Schulte-Geldermann, E. 2019. Potatolegume intercropping on a sloping terrain and its effects on soil physico-chemical properties. Plant and Soil, 438 : 447-460.

14. Gitari, H.I., Karanja, N.N., Gachene, C.K.K., Kamau, S., Sharma, K. and Schulte-Geldermann, E. 2018. Nitrogen and phosphorous uptake by potato (Solanum tuberosum L.) and their use efficiency under potato-legume intercropping systems. Field Crops Research, 222: 78-84.

15. Gitari, H.I., Mochoge, B.E. and Danga, B.O. 2015. Effect of lime and goat manure on soil acidity and maize (Zea mays) growth parameters at Kavutiri, Embu County Central Kenya. Journal of Soil Science and Environmental Management, 6: 275-283.

16. Gitari, H.I., Shadrack, N., Kamau, S., Gachene, C.K.K., Karanja, N.N. and Schulte-Geldermann, E. 2020. Agronomic assessment of phosphorus efficacy for potato 
(Solanum tuberosum L) under legume intercrops. Journal of Plant Nutrition, 43: 864-878.

17. Goulding, K.W.T. 2016. Soil acidification and the importance of liming agricultural soils with particular reference to the United Kingdom. Soil Use and Management, 32(3): 390-399.

18. Gudu, S.O., Okalebo, J.R., Othieno, C.O., Obura, P.A., Ligeyo, D.O. and Schulz, D. 2005. Response of maize to nitrogen, phosphorus and lime on acid soils of western Kenya, In: Tenywa JS, Adipala E, Nampala P, Tusiime P, Okori G, Khamuhangire (Eds.), Crop Science Conference Proceedings, Kampala, Uganda 7 (2005) 1109-1115.

19. Guignard, M.S., Nichols, R.A., Knell, R.J., Macdonald, A., Romila, C. and Trimmer, M. 2017. Genome size and ploidy influence angiosperm species' biomass under nitrogen and phosphorus limitation. New Phytology, 210: 1195-1206.

20. Hack, H., Bleiholder, H., Buhr, L., Meier, U., SchnockFricke, U., Weber, E. and Witzenberger, E. 1992. Uniform coding of the phenological stages of development of mono- and dicotyledon plants - Extended BBCH scale, general. News sheet Deut. Plant protection, 44: 265-270.

21. Hassan, M.J., Raza, M.A., Rehman, S.U., Ansar, M., Gitari, H., Khan, I., Wajid, M., Ahmed, M., Shah, G.A., Peng, Y. and Li, Z. 2020. Effect of cadmium toxicity on growth, oxidative damage, antioxidant defense system and cadmium accumulation in two sorghum cultivars. Plants, 9(11): 1575.

22. Jackson, M.L. 1967. Soil chemical analysis. Prentice Hall of India Private Limited, New Delhi.

23. Jafer, D.G. and Hailu, G. 2017. Application of Lime for Acid Soil Amelioration and Better Soybean Performance in South-Western Ethiopia. Journal of Biology, Agriculture and Healthcare, 7: 95-100.

24. Jama, B., Swinkels, R.A. and Buresh, R.J. 1997. Agronomic and economic evaluation of organic and inorganic sources of phosphorus in Western Kenya. Agronomy Journal, 89(4): 597-604.

25. Kamprath, E.J. 2015. Crop response to lime on soils in the Tropics. Soil Acidity and Liming, pp. 349-368. doi: 10.2134/ agronmonogr12.2ed.c9.

26. Kang'ethe, W.G. 2004. Agricultural development and food security in Kenya: A case for more support. A paper prepared for agriculture and food organization (September).

27. Khasawneh, F.E. and Doll, E.C. 1978. The Use of Phosphate Rock for Direct Application to Soils. Advances in Agronomy, pp. 159-206. doi: 10.1016/s0065-2113(08)60706-3.

28. Kimiti, W.W. 2018. Lime, manure and inorganic fertilizer effects on soil chemical properties, maize yield and profitability in Tharaka-Nithi County, Kenya. MSTDepartment of Environmental Science, pp. 43-44.

29. Kisinyo, P., Gudu, S., Othieno, C., Okalebo, J., Ochuodho, J. and Agalo, J. 2009. Residual effects of lime and phosphorus application on soil and maize (Zea mays L.) performance in a Kenyan highland's acid soil. Journal Agriculture Pure and Applied Science and Technology, 3: 1-10.
30. Kochian, L.V., Pineros, M.A. and Hoekenga, O.A. 2005. The physiology, genetics and molecular biology of plant aluminium resistance and toxicity, Plant and Soil, 274: 175-195.

31. Kwabiah, A., Stoskopf, N., Palm, C., Voroney, R., Rao, M. and Gacheru, E. 2003. Phosphorus availability and maize response to organic and inorganic fertilizer inputs in a short term study in western Kenya, Agriculture, Ecosystems and Environment, 95(1): 49-59.

32. Ligeyo, D.O., Gudu, S., Ombakho, G., Obura, P., Okalebo, J.R., Othieno, C., Parentoni, S.N., Magalhaes, J. and Schaffert, R. 2008. Genetic analysis of maize tolerance to aluminium toxicity. East African Agricultural and Forestry Journal, 74(1-2): 11-16.

33. Ligeyo, D.O., Gudu, S., Ombakho, G.A., Obura, P.A., Okalebo, J.R. and Othieno, C.O. 2013. Differential phosphorus uptake and P use efficiency by Kenyan maize inbreds and hybrids populations in acid soils of western Kenya, In: Alves (Edition), $3^{\text {rd }}$ International Symposium on Phosphorus Dynamics in Soil-Plant Continuum: Integrating Marginal Lands into Productive Agricultural.

34. Lino, A.C.M., Buzetti, S., Teixeira Filho, M.C.M.F., Galindo, F.S., Maestrelo, P.R. and Rodrigues, M.A.C. 2018. Effect of phosphorus applied as monoammonium phosphate-coated polymers in corn culture under notillage system. Semina, 39: 99-112.

35. Maitra, S., Hossain, A., Brestic, M., Skalicky, M., Ondrisik, P., Gitari, H., Brahmachari, K., Shankar, T., Bhadra, P., Palai, J.B., Jena, J., Bhattacharya, U., Duvvada, S.K., Lalichetti, S. and Sairam, M. 2020. Intercropping system - A low input agricultural strategy for food and environmental security. Agronomy, 11(2): 343.

36. Marschner, P. 2012. Marschner's Mineral Nutrition of Higher Plants. $3^{\text {rd }}$ Edition, Academic Press, Cambridge, $649 \mathrm{p}$.

37. Mehlich, A. 1976. New buffer $\mathrm{pH}$ method for rapid estimation of exchangeable acidity and lime requirement of soils. Communications in Soil Science and Plant Analysis, 7(7): 637-652.

38. Meng, Q., Yue, S., Chen, X., Cui, Z., Ye, Y., Ma, W., Tong, Y. and Zhang, F. 2013. Understanding dry matter and nitrogen accumulation with time-course for high-yielding wheat production in China. PLoS One, 8(7): e68783.

39. Motsara, M.R. and Roy, R.N. 2008. Guide to laboratory establishment for plant nutrient analysis. Food and Agriculture Organization of the United Nations, Rome.

40. Mugo, N.J., Karanja, N.N., Gachene, C.K., Dittert, K., Gitari, H.I. and Schulte-Geldermann, E. 2021. Response of potato crop to selected nutrients in Central and Eastern highlands of Kenya. Cogent Food E Agriculture, 7: 1898762.

41. Murphy, J. and Riley, J.P. 1962. A modified single solution method for the determination of phosphate in natural waters, Analytica Chimica Acta., 27: 31-36.

42. Nasar, J., Khan, W., Khan, M.Z., Gitari, H.I., Gbolayori, J.F., Moussa, A.A., Mandozai, A., Rizwan, N., Anwari, G. and Maroof, S.M. 2021. Photosynthetic activities 
and photosynthetic nitrogen use efficiency of maize crop under different planting patterns and nitrogen fertilization. Journal of Soil Science and Plant Nutrition. In press.

43. Nduwimana, D., Mochoge, B., Danga, B., Masso, C., Maitra, S. and Gitari, H. 2020. Optimizing nitrogen use efficiency and maize yield under varying fertilizer rates in Kenya. International Journal of Bioresource Science, 7(2): 63-73.

44. Nekesa, A.O., Okalebo, J.R., Othieno, C.O., Thuita, M.N., Bationo, A. and Waswa, B.S. 2011. The potential of increased maize and soybean production in UasinGishu District, Kenya, resulting from soil acidity amendment using Minjingu phosphate rock and agricultural lime. In: Bationo A, Waswa B, Okeyo J, Maina F, Kihara J. (Eds.), Innovations as Key to the Green Revolution in Africa. Springer, Dordrecht. doi: 10.1007/978-90-481-2543-2_34.

45. Ngugi, M.M., Gitari, H.I., Muui, C. and Gweyi-Onyango, J.P. 2021. Cadmium mobility, uptake, and accumulation in spinach, kale, and amaranths vegetables as influenced by silicon fertilization. Bioremediation Journal, doi:10.1080 /10889868.2021.1924111.

46. Nyawade, S., Gitari, H.I., Karanja, N.N., Gachene, C.K., Schulte-Geldermann, E., Sharma, K. and Parker, M. 2020. Enhancing climate resilience of rain-fed potato through legume intercropping and silicon application. Frontier in Sustainable Food Systems, 4: 566345.

47. Nyawade, S.O., Gachene, C.K.K., Karanja, N.N., Gitari, H.I. and Schulte-Geldermann, E. 2019. Controlling soil erosion in smallholder potato farming systems using legume intercrops. Geoderma Regional, 17: e00225.

48. Nyoro, J., Kirimi, L. and Jayne, T.S. 2004. Competitiveness of Kenyan and Ugandan maize production: Challenges for the future, Working Paper 10, Egerton University, Tegemeo Institute, Nairobi.

49. Ochieng' , I.O., Gitari, H.I., Mochoge, B., Rezaei-Chiyaneh, E. and Gweyi-Onyango, J.P. 2021. Optimizing maize yield, nitrogen efficacy and grain protein content under different $\mathrm{N}$ forms and rates. Journal of Soil Science and Plant Nutrition. doi:10.1007/s42729-021-00486-0.

50. Okalebo, J.R. 2009. Potential for agricultural lime on improved soil health and agricultural production in Kenya. African Crop Science Journal, 9: 339-341.

51. Otieno, M.A., Gitari, H.I., Danga, B. and Karuma, A.N. 2021. Soil properties and fertility management with respect to Capsicum (Capsicum annuum L.) production in Nairobi Peri-urban Counties. Journal of Soil Science and Plant Nutrition. In press.

52. Pennock, D., Yates, T. and Braidek, J. 2006. Soil sampling design. In: Carter MR, Gregorich EG. (Eds.), Soil sampling and methods of analysis, $2^{\text {nd }}$ Edition, Taylor and Francis Group LLC, London.

53. Rajeshwari, R.S., Hebsur, S., Pradeep, H.M. and Bharamagoudar, T.D. 2007. Effect of integrated nutrient management on growth and yield of maize. Karnataka Journal of Agricultural Science, 20: 399-400.
54. Raza, M.A., Gul, H., Wang, J., Yasin, H.S., Qin, R., Khalid, M.H.B., Naeem, M., Feng, L.Y., Iqbal, N., Gitari, H., Ahmad, S., Battaglia, M., Ansar, M., Yang, F. and Yang, W. 2021. Land productivity and water use efficiency of maize-soybean strip intercropping systems in semi-arid areas: A case study in Punjab Province, Pakistan. Journal of Cleaner Production, 308: 127282.

55. Ryan, J., George, E. and Rashid, A. 2001. Soil and Plant Analysis Laboratory Manual. Second edition. Jointly published by the International Center for Agricultural Research in the Dry Areas (ICARDA) and the National Agricultural Research Centre (NARC), pp. 46-48.

56. Sadik, G. and Asm, M.G. 2001. Antifertility Activity of Pergulariadaemia. Journal of Medical Sciences (Faisalabad), 1(1): 22-24.

57. Sanchez, P.A., Shepherd, K.D., Soule, M.J., Place, F.M., Buresh, R.J., Izac, A.M., Mokwunye, A.U., Kwesiga, F.R., Ndiritu, C.N. and Woomer, P.L. 1997. Soil fertility replenishment in Africa: an investment in natural resource capital. In: Buresh et al. (Eds). Replenishing Soil Fertility in Africa. SSSA Special Publication No. 51. Madison, Wisconsin, USA.

58. Sandana, P. 2016. Phosphorus uptake and utilization efficiency in response to potato genotype and phosphorus availability. European Journal of Agronomy, 76: 95-106.

59. Sanginga, N. and Woomer, P.L. 2009. Integrated soil fertility management in Africa: principles, practices and developmental process. Tropical Soil Biology and Fertility Institute of the International Centre for Tropical Agriculture, Nairobi, pp. 263.

60. Seleiman, M.F., Aslam, M.T., Alhammad, B.A., Hassan, M.U., Maqbool, R., Chattha, M.U., Khan, I., Gitari, H.I., Uslu, O.S., Roy, R. and Battaglia, M.L. 2021. Salinity Stress in Wheat: Effects, Mechanisms and Management Strategies. Phyton- International Journal of Experimental Botany. doi: 10.32604/phyton.2022.017365.

61. Schachtman, D.P., Reid, R.J. and Ayling, S.M. 1998. Phosphorus uptake by plants: From Soil to Cell. Plant Physiology, 116(2): 447-453.

62. Sklensky, D.E. and Davies, P.J. 1993. Whole plant senescence: reproduction and nutrient partitioning. Horticultural Reviews, 15: 335-366.

63. Soratto, R.P., Parecido, R.J., Perdoná, M.J., Guidorizzi, F.V.C., Gitari, H.I., Gomes, G.G. and Paula, R.A. 2021. Limestone increased coffee yield and profitability more than phosphogypsum or their combination. Agronomy Journal. doi: 10.1002/agj2.20712.

64. Swift, M.J., Dvorak, K.A., Mulongoy, K., Musoko, M., Sanginga, N. and Tian, G. 1994. The role of soil organisms in the sustainability of tropical cropping systems, In: Syers JK, Rimmer, DL. (Eds.), Soil Science and Sustainable Land Management in the Tropics, CAB International, Cambridge University Press.

65. Tisdale, S.L., Nelson, W.L. and Beaton, J.D. 1990. Soil fertility and fertilizers: Elements required in plant nutrition. $4^{\text {th }}$ Edition. Maxwell MacMillan Publishing, Singapore, pp. 52-92. 
66. Uribelarrea, M., Crafts-Brandner, S.J. and Below, F.E. 2008. Physiological $\mathrm{N}$ response of field-grown maize hybrids (Zea mays L.) with divergent yield potential and grain protein concentration. Plant and Soil, 316(1-2): 151-160.

67. Vance, C.P., Uhde-Stone, C. and Allan, D.L. 2003. Phosphorus acquisition and use: critical adaptations by plants for securing a nonrenewable resource. New Phytologist, 157(3): 423-447.

68. Veneklaas, E.J., Lambers, H., Bragg, J., Finnegan, P.M., Lovelock, C.E., Plaxton, W.C. and Raven, J.A. 2012. Opportunities for improving phosphorus-use efficiency in crop plants. New Phytologist, 195(2): 306-320.

69. Waigwa, M.W., Othieno, C.O. and Okalebo, J.R. 2002. Phosphorus availability as affected by the application of phosphate rock combined with organic materials to acid soils in western Kenya. Experimental Agriculture, 39(4): 395-407.

70. Wang, C. and Ning, P. 2019. Post-silking phosphorus recycling and carbon partitioning in maize under low to high phosphorus inputs and their effects on grain yield. Frontiers in Plant Science, 10: 784.

71. Wang, F., Sims, J.T., Ma, L., Ma, W., Dou, Z. and Zhang, F. 2011. The phosphorus footprint of China's food chain: implications for food security, natural resource management, and environmental quality. Journal of Environmental Quality, 40: 1081.
72. Yan, H., Shang, A., Peng, Y., Yu, P. and Li, C. 2011. Covering middle leaves and ears reveals differential regulatory roles of vegetative and reproductive organs in root growth and nitrogen uptake in maize. Crop Science, 51: 265-272.

73. Yaseen, M. and Malhi, S.S. 2009. Differential growth performance of 15 wheat genotypes for grain yield and phosphorus uptake on a low phosphorus soil without and with applied phosphorus fertilizer. Journal of Plant Nutrition, 32(6): 1015-1043.

74. Yeomans, J.C. and Bremner, J.M. 1988. A rapid and precise method for routine determination of organic carbon in soil, Communications in Soil Science and Plant Analysis, 19(13): 1467-1476.

75. Zhou, T., Wang, L., Li, S., Gao, Y., Du, Y., Zhao, L., Liu, W. and Yang, W. 2019. Interactions between light intensity and phosphorus nutrition affect the P uptake capacity of maize and soybean seedling in a low light intensity area. Frontiers in Plant Science, 10: 183.

76. Zhou, T., Wang, Li., Sun, X., Wang, X., Pu, T., Yang, H., Rengel, Z., Liu, W. and Yang, W. 2021. Improved post-silking light interception increases yield and P-use efficiency of maize in maize/soybean relay strip intercropping. Field Crops Research, 262: 10854. 